\title{
Teaching English to Young Learners: Students' Interference on Pre-Reading Skill in Preparing School Readiness
}

\author{
Sharina Munggaraning Westhisi $1^{1, *}$ \\ ${ }^{1}$ Early Childhood Teacher Education Department, Institut Keguruan dan Ilmu Pendidikan Siliwangi, Cimahi, Indonesia \\ *Corresponding author. Email: sharina@ikipsiliwangi.ac.id
}

\begin{abstract}
Industrial revolution 4.0 encourages people to develop their skills, for instance literacy skills. English literacy is needed since people should be able to participate globally which might be commenced in Early Childhood Education (ECE). The English instruction for non-native young learners needs numerous methods to deliver the materials in a proper way, purposely the pre-reading instruction for young learners in preparing for school readiness. Pre-reading skill would be emphasized on introduction of English letters sounds as a foundation in developing reading skill in the future. This article unpacks teaching practices in English pre-reading skill to young learners which involve children as role model for their peers. It uses qualitative descriptive study which involves two teachers and children aged four and five years old. It reveals that students' interference in an English instruction of pre-reading skill is able to assist them to comprehend the concept of English letter sounds, to increase the student's confidence in learning English, to improve their fluency in English, and to create contextual environment of learning.
\end{abstract}

Keywords: English to young learners, pre-reading, school readiness

\section{INTRODUCTION}

Literacy is an ability to think critically, to be able to solve problems in various contexts, to be able to communicate effectively, and to be able in enhancing potential and actively participating in social life (Alberta, 2010). In other words, literacy is more than just reading and writing. Gerakan Literasi Nasional or the National Literacy Movement is a form of realization and is an effort from the government program to improve life skills and selfquality, to increase productivity and competitiveness globally, and to develop the nation's characters. Those should be achieved through literacy activities that occur in schools, in family and in society. There are some literacies carried out by the government in order to achieve the national objectives, one of them is language literacy.

In this industrial revolution 4.0, people are facilitated with internet connection which can be accessed anytime and anywhere to gather information from around the world. The data in 2016, obtained from the Indonesian internet service providers association, showed that $65 \%$ of 132,7 million internet users are based in Java and $69,8 \%$ of the internet users are students who tend to access negative contents and features (Atmazaki, et al., 2017). This indicates that accessing internet is a basic need for people. Ironically, the survey about literacy conducted in 2016 by the Central Connecticut State University in New Britain, Conn, United State showed that Indonesia is placed 60th out of 61 countries (Atmazaki, et al., 2017). Moreover, the Indonesia National Assessment Program (INAP) measured reading, mathematics, and science skills of elementary students and the result showed that those skills are poor which consist of $77,13 \%$ in mathematics, $73,61 \%$ in science, and 46,8 \% in reading (Atmazaki, et al., 2017). The results of the survey in regard to literacy skill, for instance reading activities, promote the practitioners, teachers, parents, and government to create a proper program or activities of reading in early childhood.

The compliance of skills in order to increase productivity and competitiveness globally in the era 4.0 is through acquiring foreign language, especially English that can be learned in early childhood. Children, at age five, have a dynamic language development. For instance, they possess the vocabulary of approximately 5000-8000 words (Seefeldt \& Wasik, 2008). This ability should be used to acquire English as a foreign language in early childhood. Regarding language literacy, one of the activities is through reading. Pre-reading skill should be practiced in order to develop literacy skills (Suggate, Schaughency, \& Reese, 2013. The teaching practice of pre-reading skills through phonics method is able to be implemented in Early Childhood Education (ECE), for instance introduction of letter sounds (Lyster, Lervag, \& Hulme, 2016). This indicates that pre-reading skill in ECE can be achieved through phonics method.

For teaching practices, teachers should consider some characteristics, needs, and interests of the children. It is necessary to create positive ambience and environment that assist them to reach learning objectives. The presence of a teacher is inadequate in learning process, even if the teacher provides space and time to express what children 
do and want. Children need peers to support the learning process. Vygotsky's theory believed that children are able to get the knowledge from social experiences and need someone else to encourage them in achieving skills beyond theirs (Pinter, 2006). The power of peers in learning process is valuable as teacher and peers are able to be a role model for children in learning process.

The previous studies conducted regarding the implementation and benefits of phonics method showed that children comprehended the concept of phonics which is a foundation on developing reading skill to a higher level (Farokhbakht \& Nejadansari, 2015). Teaching English for non-native speakers, a study showed that phonics method could help the children to develop early reading (Jamaludin, Alias, \& Mohd, 2016). Furthermore, National Early Literacy Panel (NELP) stated that phonics recognition is the strongest predictor in reading which can be integrated with knowledge, phonics implementation, and evaluation verbally (NELP, 2008). Another study related to peer relationship in learning for ECE showed that students' interference during learning process is necessary since they can give positive attitudes towards the environment, for instance their peers (Körükçü \& Gülay, 2015). Stanton-Chapman (2014) believed that teacher is able to assist the children to build the positive relationship among peers by providing and facilitating the physical environment, for instance toys selection and themes. According to the author's experiences, parents have an ambition towards their children to acquire English and they want to give the best education for the children by enrolling them to international schools where English is the main language and demanding them to be capable of reading before they go to primary school. Besides, majority of the teaching of English to non-native young learners, particularly in developing pre-reading skills, is done through drilling and one-way communication. Students are asked to pronounce and to repeat what the teacher says without providing opportunities for attempting on comprehending the concept of phonics and on constructing the peer relationship in order to develop the social skills as well. In addition, a non-native English child feels anxious, shy, and insecure to join the class.

Based on the phenomena above, a comprehensive research is needed to unpack the students' interference in teaching English practices in order to develop pre-reading skills on preparing school readiness.

\section{METHOD}

This article used a descriptive qualitative method which involved two teachers and eight children, aged four and five years old. It took place in Bandung, in one of the English courses for early childhood. The research was conducted for nine months. The data were gathered twice a week in that one session took 60 minutes to conduct. The author used observation to find out the attitudes and responses of the children during the learning process, and to analyze the teachers' attitudes to encourage children to get into the learning activity. Then, interview was employed to obtain the data from the teachers regarding the strategies that might be used to make the students involve into the learning activities in order to develop prereading skill. Lastly, study documentation was used to identify the learning objectives of pre-reading skill, especially for non-native children. Thematic analysis was used to discover two themes. The first theme is prereading skill for non-native English speaker and the other theme is students' interference on pre-reading practices.

\section{RESULT AND DISSCUSSION}

\subsection{Pre-Reading Skill for Non-Native English Speaker (NNES)}

Pre-reading for Non-Native English Speaker (NNES) through phonics method for early childhood has three levels. They are introduction of letter sounds, introduction of letter symbols, and blending the letter sounds. The introduction of letter sounds is divided into three sections, which are first, middle, and last sounds. It means that the children should pronounce the first sound of the word, for instance hat, they have to pronounce / $\mathrm{h} /$ as the first sound, $/ \mathrm{t} /$ as the last sound, and $/ æ /$ as the middle sound. Furthermore, the teacher teaches the first sound, then last sound, and middle sound. It is an interesting finding in this study in which the teacher teaches the middle sound at the end. The reason is that teaching first and last sound will be easier. The teacher strongly believed that the children will be easier to comprehend the concept of middle sound after they master and comprehend the concept of first and the last sounds. It becomes a new thing since Genishi and Fassler merely stated the characteristics of this method focus on phonology (Wortham, 2006). It is not explained in detail about the stages to introduce the letter sounds to early childhood.

The introduction of letter sounds has been done verbally. The teacher showed the picture board which has 30 small boxes that represent each letter sounds. The letters are 26 of alphabet and four consonant digraph sounds which are ch, sh, ng, th. Afterward, the children start recognizing the symbol of letters by looking at the last page of their workbook or on the alphabet board. In the beginning, the teacher showed the symbol of letters and asked the children to listen and repeat what the teacher pronounced. The stimuli and responses contribute to the positive energy in learning language (Palermo, 1978). It is done gradually by listening, repeating, reinforcing, and rewarding. Each meeting, the teacher showed three to five letters since the children have different ability to memorize them. Considering the children's intelligences, the teacher should accommodate them to acquire the reading skill. The prereading practices regarding the introduction of letter sounds and symbols can be modified, for instance the teacher may choose three letters for each meeting. The teacher introduces the sound and the symbol simultaneously in order to facilitate the children who have 
various intelligences since the children will be more interested in what they see and hear. Furthermore, the symbol of letters should be colorful and unique.

Recognizing the letter sounds and symbols assists the children to blend sounds. It is an important part to develop reading skill in the next level where phonics method engages blending, arranging, segmenting, and changing the sounds (Ghoneim \& Elghotmy, 2015). The children blend the sound to read. In this level, they learn how to blend two to four sounds verbally that consist of consonant (C) and vocal (V) which are CV, CVC, CVCC, and CCVC. In the practices, the teacher mentioned the sounds and the children would blend them, for instance: (1) CV is ma, mi, mu, mo, etc.; (2) CVC is bag, mot, sat, sit, etc.; (3) CVCC is palm, sand, etc.; (4) CCVC is play, ploy, etc. Usually, the teacher pronounced the simple sounds such as $\mathrm{s}, \mathrm{m}$, and f. For those who are fast learners, the teacher taught digraph sounds such as the words of ship, moth, ring, chip, and so on. Furthermore, at the end of the term, the children may choose the word card by themselves to do the blending activity. They blend the sounds of a word independently. It could be better if the teacher provides the words which has two or more syllables and teach how to blend them since the children may be confused if they have to blend many sounds of one word. The proper strategies are needed to teach how to blend the sounds of the words which have two or more syllables.

Pre-reading practices are integrated with other skills, particularly listening and speaking skills, in order to give the opportunity for children in developing their language skills simultaneously. The outcome of the children may vary since it depends on age, level of exposures, first language and also the ability of reading skill in first language (Pinter, 2006). Thus, it is a paramount thing that the children should acquire their first language well before they learn second or foreign language in order to relieve puzzlement and anxiety in learning.

\subsection{Students' Interference on Pre-Reading Practices}

Students' interference in this study means engaging children to be a role model for their peers. It can be seen during the practices when the teacher asked one student to come forward to choose one picture from the picture board. This is an example on how the students are engaged into the practices. Then, the teacher asked a student to ask another student about letter sounds. It gives opportunities for them to learn directly the use of English. They not only merely listen but also learn how to speak in English unconsciously. However, there was a student who was shy and did not speak at all. To respond this case, the teacher did not push that student to speak or come forward. It is a great decision for teachers to face the students who are shy or do not want to involve to the practices. There are some reasons, for instance, the student needs time to adapt to the environment or the strangers.
The strategies used in pre-reading practices are games since students like playing games a lot. Furthermore, games are the basic approach for early childhood to learn. The popular media used are flash cards, puzzles, and story books. Those are called Educational Magical Toys (EMT) which give effective practices since it builds the environment which provides the students to have interactive games and learning (Yilmaz, 2016). Regarding the use of media in teaching early childhood in this digital era, it is necessary to do a collaboration and modification between technology and media in order to create the digital media which are able to reduce boredom while learning, especially for the English course when the students are already exhausted from school and have to go to a course place for extra lesson.

The students enjoyed the games such as Domino, Building a Bridge, Matching Time, and Train Words. The students' inference on pre-reading practices can be seen in those games, for instance in the games Building a Bridge. The student took one card and asked his peer who sat beside him to mention the name of the picture, the first, middle, and last sounds. If it was correct the student would get the card and started building a bridge. Yet, if the student cannot answer correctly, the teacher would ask another children to assist him. It means that peers gave positive effects and that student could be a role model for them (Stanton-Chapman, 2014). This was proven when one student could not answer correctly, others assisted him directly without making fun or laughing at that one student. Another example is when a student could not find a picture on the board, his peers came and pointed to the correct picture without being told by the teacher. This is the evidence that students can be a teacher as well for peers in practices by providing experiences and opportunities to learn contextually.

The students' interference affects the development of speaking skill, comprehends the concept of phonics, pronounce sounds clearly and fluently, and increases the confidence to speak in English. The role of the students in the pre-reading practices is valuable. It can be seen that the students are able to transfer and to share the knowledge with their peers. Thus, they are capable of achieving beyond the learning objectives.

\section{CONCLUSION}

Teaching English to young learners in pre-reading skill can be commenced in early childhood education through phonics method which consists of letter sounds, letter symbols, and blending sounds. The practices are suitable for NNES who want to develop the pre-reading skill in preparing for school readiness. During the process, the teacher should involve students and make them as role models for their peers since it affects them to build confidence in speaking, to comprehend the concept of phonics definitely, to pronounce the sounds clearly, and to speak English fluently. Moreover, the use of various media and strategies are necessary to create a contextual and an entertaining learning. 


\section{ACKNOWLEDGMENT}

The author would like to thank the teachers, from the English course in Bandung, who are very helpful to contribute information related to the topic, to the parents who were willing to have their children observed, and also to the children who are brilliant during the learning process. Thus, this research could run well and smoothly.

\section{REFERENCES}

Alberta. (2010). Literacy first-A plan for action, government of alberta. Retrieved from www.education.alberta.ca/media.

Atmazaki, et al. (2017). Panduan gerakan literasi nasional. Jakarta: Kementrian Pendidikan dan Kebudayaan.

Farokhbakht, L., \& Nejadansari, D. (2015). The effect of using synthetic multisensory phonics in teaching literacy on EFL young learners' literacy learning. International Journal of Research Studies in Education, 4(4), 39-52. doi:10.5861/ijrse.2015.1196

Ghoneim, N. M. M., \& Elghotmy, H. E. A. (2015). The Effect of a Suggested Multisensory Phonics Program on Developing Kindergarten Pre-Service Teachers' EFL Reading Accuracy and Phonemic Awareness. English Language Teaching, 8(12), 124-143. doi: https://doi.org/10.5539/elt.v8n12p124

Jamaludin, K. A., Alias, N., \& Mohd, R. J. (2016). The effectiveness of synthetic phonics in the development of early reading skills among struggling young ESL readers. School Effectiveness and School Improvement, 27(3), 455-470. doi: 10.1080/09243453.2015.1069749

Körükçü, Ö., \& Gülay Ogelman, H. (2015).

Relationship between the preschool children's attitudes towards the environment and their social status. Early Child Development and Care, 185(2), 171-180. doi:10.1080/03004430.2014.908867

Lyster, S. A. H., Lervag, A. O., \& Hulme, C. (2016). Preschool morphological training produces long-term improvements in reading comprehension. Reading and writing, 29(6), 1269-1288.

National Early Literacy Panel. (2008). Developing early literacy: report of the national early literacy panel. Washington: National Institute for Literacy. Retrieved from http://www.nifl.gov/earlychildhood/NELP/ NELPreport.html

Palermo, D. S. (1978). Psychology of language. Dallas: Scott Foresman.

Pinter, A. (2006). Teaching young language learners. Oxford: Oxford University Press.

Seefeldt, C., \& Wasik, B. A. (2008). Pendidikan anak usia dini: Menyiapkan anak usia tiga, empat, dan lima tahun masuk sekolah. Jakarta: PT. Indeks.

Stanton-Chapman, T.L. (2014). Promoting positive peer interactions in the preschool classroom: The role and the responsibility of the teacher in supporting children's sociodramatic play. Early Childhood Education Journal, 43(2), 99-107. doi:10.1007/s10643-014-06358

Suggate, S. P., Schaughency, E. A., \& Reese, E. (2013). Children who learn to read later catch up to children who learn to read early. Early Childhood Research Quarterly, 23, 33-48. doi:http://dx.doi.org/10.1016/j.ecresq.2012.04.004

Wortham, S.C. (2006). Early childhood curriculum: Development bases for learning and teaching (4th ed.). New Jersey: Pearson.

Yilmaz, R. M. (2016). Educational magic toys developed with augmented reality technology for early childhood education. Computers in human behavior, 54, 240-248. doi:http://dx.doi.org/10.1016/j.chb.2015.07.040. 